\title{
Multiple alternate-sided percutaneous vertebroplasties
}

\author{
Marc Prod'homme 다, ${ }^{1}$ Didier Grasset, ${ }^{1}$ Marie-Pierre Raemy, ${ }^{2}$ Duccio Boscherini ${ }^{1}$
}

${ }^{1}$ Neuro Orthopedic Center, La Source College of Health, Lausanne, Switzerland ${ }^{2}$ Operating Theatre, La Source College of Health, Lausanne, Switzerland

Correspondence to Dr Marc Prod'homme; marcprod86@gmail.com

Accepted 19 August 2021

\section{DESCRIPTION}

Vertebral compression fractures (VCF) are frequent injuries mostly related to bone fragility ${ }^{1}$ and are successfully treated by cementoplasty, such as vertebroplasty or kyphoplasty. ${ }^{2}{ }^{3}$ Vertebroplasty requires the use of two-dimensional (2D) imaging for intraoperative control of cement filling. Threedimensional (3D) imaging with computerised navigation offers more accurate procedure. ${ }^{4}$ Ionising radiation level related to the use of imaging devices may be estimated with the calculation of the effective dose E. ${ }^{5}$ A 57-year-old female patient, known for a metastatic pancreas cancer since 2018, came to our office because of progressive back pain. The patient clinically presented with a pain on numeric rating scale (NRS) of 6/10 from the mid-thoracic region to the whole lumbar region, increasing with manual percussion on the midline, but she was neurologically intact. Thoracolumbar MRI showed multiple ${ }^{6}$ osteoporotic VCF from T9 to L5: three concave and six bow-shaped types according to Sugita et al (figure 1). A percutaneous multilevel vertebroplasty procedure was scheduled with 3D navigation aided by the $\mathrm{O}$-arm (O-arm Surgical Imaging System, Medtronic, Minneapolis, Minnesota, USA), and X'Pede cement (Medtronic, Minneapolis, Minnesota, USA) was used. Two 3D acquisitions were required to cover first the vertebrae L2 to L5, and second the vertebrae T9 to L2. Each vertebra was accessed through an extrapedicular single approach

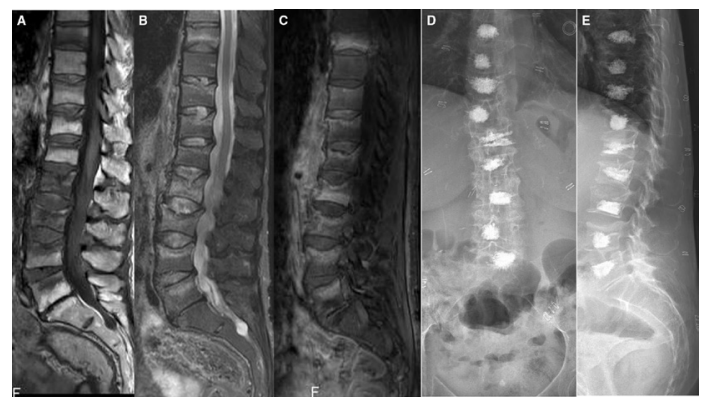

Figure 1 Preoperative and postoperative thoracolumbar imaging. (A) T1-weighted MRI showed multiple vertebral compression fractures from T9 to L5 classified as concave-type for L4 and L5 and bowshaped type for the remaining vertebrae according to Sugita et al. ${ }^{6}$ (B) T2-weighted MRI showed hypersignal of the vertebrae T9 to L5 excepted to T10. (C) T1weighted and gadolinium MRI showed hypersignal of the same vertebrae, confirming acute fractures. (D and E) Postoperative radiographs showed adequate cement filling from X3 to Z3 according to the Garnier classification $^{11}$ and no cement leakage.
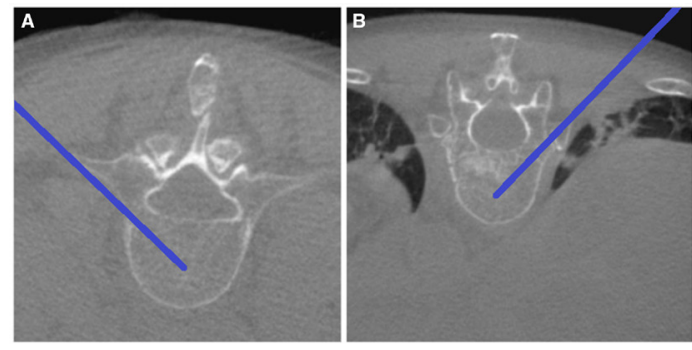

C

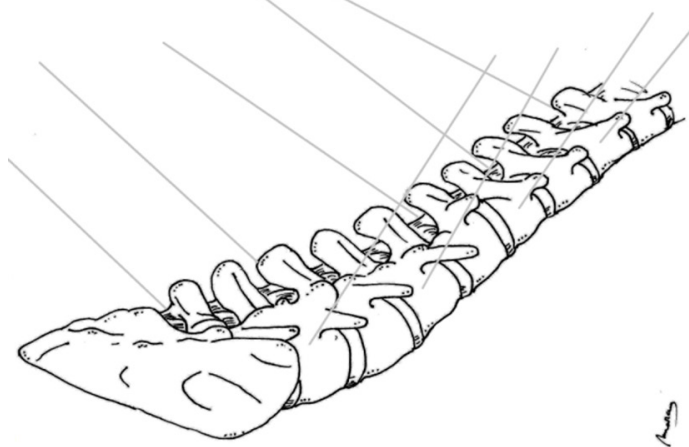

Figure 2 Intraoperative imaging axial view (A, B) of the extrapedicular vertebroplasty procedure. The Jamshidi needle was introduced laterally in direction to the centre of the vertebral body at each level, from a side for one vertebra, and the opposite side for the upper vertebra as an alternate-sided pattern. Drawing of the technique principle (C). Illustration: Marcus. (c) BMJ Publishing Group Limited 2021. No commercial re-use. See rights and permissions. Published by BMJ.

To cite: Prod'homme M, Grasset D, Raemy M-P, et al. BMJ Case Rep

2021:14:e243095

doi:10.1136/bcr-2021-

243095 of the Jamshidi-navigated needle (PAK Needle, Medtronic, Minneapolis, MN, USA) introduced in the vertebral body (figure 2) from an alternate side. For thoracic vertebrae, the needle position was at the junction of the transverse process and rib below the superior articular facet joint of the vertebra to be cemented, ${ }^{7}$ and for lumbar vertebrae, through a far lateral extrapedicular approach according to Ryu et al. ${ }^{8} 2 \mathrm{D}$ mode of the O-arm was used for cement injection control, 18 cubic centimetres (cc) of viscous cement for the whole procedure (about $2 \mathrm{cc}$ per vertebra). After removing all trocars, staples were used for skin closure. The whole procedure duration from incision to closure was $40 \mathrm{~min}$. Blood loss was $20 \mathrm{cc}$. Effective dose (E, in $\mathrm{mSv}$ ) was calculated with the dose length product (DLP, in $\mathrm{mGy} . \mathrm{cm}$ ) and the dose area product (DAP, $\mathrm{mGy} . \mathrm{cm}^{2}$ ) according to the recommendations of the International Commission of Radiological Protection' using conversion factors $k=0.015 \mathrm{mSv} / \mathrm{mGy}$. $\mathrm{cm}$ and $w=0.26 \mathrm{mSv} / \mathrm{Gy} \cdot \mathrm{cm}^{2}$, such as $\mathrm{E}_{3 \mathrm{D}}=\mathrm{DLP}$ $\mathrm{x} k$ and $\mathrm{E}_{2 \mathrm{D}}=$ DAP $\mathrm{x} w$, leading to an overall $\mathrm{E}$ of $5.54 \mathrm{mSv}$. This result was slightly higher than 
annual natural irradiation in Switzerland $(4.32 \mathrm{mSv}) .{ }^{10}$ Postoperative radiographs showed adequate cement filling ${ }^{11}$ without any leakage (figure 1 ). Pain level decreased to $2 / 10$ postoperatively on the NRS.

The most important finding in this case was the short operative time and blood loss, with good clinical and radiological results. $3 \mathrm{D}$ navigation was particularly effective to save time with a high accuracy.

Moulin et $\mathrm{al}^{12}$ reported results of 24 multilevel vertebroplasties through the same procedure on more than 6 levels of VCF in patients with cancer. Operative time was higher, with a mean of $167 \mathrm{~min}$. The authors concluded as a safe and effective technique, similarly to the current case.

\section{Patient's perspective}

When I saw the senior surgeon at his office, I almost could not move because of progressive and intense back pain. I agreed for the surgery with the expectation of good pain relief. When I arrived at the clinic, my pain level was a continuous $6 / 10$ and prevented me from walking in a normal position. I could only walk short distances with difficulty and bent forwardly. After the surgery, I felt less pain, 2/10, and my mobility immediately improved. I felt really relieved.

\section{Learning points}

Percutaneous single-approach extrapedicular multilevel vertebroplasty was safe and effective.

- Three-dimensional navigation helped to perform more accurate surgery and to save time.

- Alternate-sided pattern helped performing effective and quick surgery, as no trocar was bothering or cumbersome on the operative field.

Contributors MP designed the study, operated and followed the patient collected data, wrote the first draft of the manuscript. DG followed the patient, performed critical revision of the manuscript. MPR performed critical revision of the manuscript. DB designed the study, operated and followed the patient, performed critical revision of the manuscript. All authors read and approved the final version of the manuscript.

Funding The authors have not declared a specific grant for this research from any funding agency in the public, commercial or not-for-profit sectors.

Competing interests None declared.

Patient consent for publication Consent obtained directly from patient(s)

Provenance and peer review Not commissioned; externally peer reviewed.

\section{ORCID iD}

Marc Prod'homme http://orcid.org/0000-0002-8646-3342

\section{REFERENCES}

1 Taylor RS, Taylor RJ, Fritzell P. Balloon kyphoplasty and vertebroplasty for vertebral compression fractures: a comparative systematic review of efficacy and safety. Spine 2006;31:2747-55.

2 Zhu Y, Cheng J, Yin J, et al. Therapeutic effect of kyphoplasty and balloon vertebroplasty on osteoporotic vertebral compression fracture: a systematic review and meta-analysis of randomized controlled trials. Medicine 2019;98:e17810.

3 Muto M, Guarnieri G, Giurazza F, et al. What's new in vertebral cementoplasty? Br J Radiol 2016:89:20150337.

4 Laine T, Lund T, Ylikoski M, et al. Accuracy of pedicle screw insertion with and without computer assistance: a randomised controlled clinical study in 100 consecutive patients. Eur Spine J 2000;9:235-40.

5 National Research Council. Health risks from exposure to low levels of ionizing radiation: BEIR VII phase 2. National Academies Press, 2006.

6 Sugita M, Watanabe N, Mikami Y, et al. Classification of vertebral compression fractures in the osteoporotic spine. J Spinal Disord Tech 2005;18:376-81.

7 Han KR, Kim C, Eun JS, et al. Extrapedicular approach of percutaneous vertebroplasty in the treatment of upper and mid-thoracic vertebral compression fracture. Acta Radiol 2005:46:280-7.

8 Ryu K-S, Park C-K, Kim M-K, et al. Single balloon kyphoplasty using far-lateral extrapedicular approach: technical note and preliminary results. J Spinal Disord Tech 2007;20:392-8.

9 European Commission, 2013. Available: https://ec.europa.eu/energy/sites/ener/files/ documents/seminar_proceedings_radiation_protection_series_ndeg_rp 182.pdf [Accessed 13 Jul 2020].

10 Office fédéral de la santé publique, 2016, forum nucléaire. Available: https://www. ensi.ch/wp-content/uploads/sites/4/2017/06/ENSI_Strahlenschutzbericht_2016_AN10020_WEB-2.pdf [Accessed 4 Sep 2019]

11 Garnier L, Tonetti J, Bodin A, et al. Kyphoplasty versus vertebroplasty in osteoporotic thoracolumbar spine fractures. short-term retrospective review of a multicentre cohort of 127 consecutive patients. Orthop Traumatol Surg Res 2012;98:S112-9.

12 Moulin B, Delpla A, Tselikas L, et al. Multi-Level vertebroplasty for 6 or more painful osteoporotic vertebral body compression fractures performed in the same procedural setting: a safety and efficacy report in cancer patients. Cardiovasc Intervent Radiol 2020;43:1041-8

Copyright 2021 BMJ Publishing Group. All rights reserved. For permission to reuse any of this content visit

https://www.bmj.com/company/products-services/rights-and-licensing/permissions/

BMJ Case Report Fellows may re-use this article for personal use and teaching without any further permission.

Become a Fellow of BMJ Case Reports today and you can:

- Submit as many cases as you like

- Enjoy fast sympathetic peer review and rapid publication of accepted articles

- Access all the published articles

- Re-use any of the published material for personal use and teaching without further permission

Customer Service

If you have any further queries about your subscription, please contact our customer services team on +44 (0) 2071111105 or via email at support@bmj.com.

Visit casereports.bmj.com for more articles like this and to become a Fellow 